\title{
Synthesis and evaluation of platinum complexes with potential antitumor activity
}

\author{
Rachel Lima Marcelino Freire', Maria Betânia de Freitas Marques', Elaine Maria de Souza- \\ Fagundes $^{2}$, Renata Barbosa de Oliveira1, Ricardo José Alves ${ }^{1 *}$
}

\begin{abstract}
${ }^{1}$ Departamento de Produtos Farmacêuticos, Faculdade de Farmácia, Universidade Federal de Minas Gerais, Belo Horizonte, MG, Brasil, ${ }^{2}$ Departamento de Fisiologia e Biofísica, Instituto de Ciências Biológicas, Universidade Federal de Minas Gerais, Belo Horizonte, MG, Brasil
\end{abstract}

\begin{abstract}
A novel series of platinum (II) complexes was synthesized and the complexes were evaluated for their in vitro cytotoxicity against four human cancer cells lines. Five platinum complexes showed activity against at least one tumor cell line. Complexes $\mathbf{3}$ and $\mathbf{6}$ were promising, being active, at micromolar concentrations, against all the assayed tumor cell lines. Compound $\mathbf{3}$ was selected for further studies in mice with Ehrlich solid tumors and it was able to reduce the rate of tumor growth significantly during the first seven days. However, at the end of the experiments, there was no significant difference between the group of animals treated with $\mathbf{3}$ and the control group. The low solubility of the compound in the assay conditions can explain, at least in part, these results.
\end{abstract}

Uniterms:. /Cytotoxic activity. Platinum complexes/ Ehrlich solid tumor activity.

\section{INTRODUCTION}

Considered as a public health problem, cancer affects people of all ages, races, gender and nationality. It is the second major cause of death by disease worldwide. According to World Health Organization, 8.2 million people worldwide died from cancer in 2012 and this number is expected to rise to 13.1 million deaths in 2030 (WHO, 2015).

Cisplatin [cis-diamminedichloroplatinum (II)] is an antitumor drug used to treat different types of cancer, including testicular cancer, germ cell cancer, lymphoma, and ovarian cancer. It is one of the most widely used and effective antineoplastic agents (Gómez-Ruiz et al., 2012). However, its clinical usefulness is often limited by severe side effects, such as nephrotoxicity, ototoxicity and neurotoxicity, and development of resistance by cancer cells. The mechanism of action of cisplatin involves its interaction with DNA to form DNA adducts, primarily intrastrand crosslink adducts (Gómez-Ruiz et al., 2012; Florea, Büsselberg, 2011).

\footnotetext{
*Correspondence: R. J. Alves. Departamento de Produtos Farmacêuticos. Faculdade de Farmácia. Universidade Federal de Minas Gerais (UFMG). Av. Antônio Carlos 6627, 31270-901, Belo Horizonte, MG, Brasil. Tel: +55-31-34096955 / Fax: +55-31-34096755. E-mail: dylancover@gmail.com
}

Extensive research efforts have been directed towards the development of novel platinum compounds with a broader spectrum of antitumor activity, reduced side effects and having improved pharmacokinetic properties. Besides, the design of new platinum-based anti-cancer agents might help to overcome cisplatin resistance. The search for new platinum complex is an ever present issue because of the potential of this class of compounds as antitumor agents (Hildebrandt et al., 2016; Lakomska et al., 2016; Pollak, Goddard, Porschke, 2016; Popova et al., 2016; Rehm et al., 2016; Wang et al., 2016).

Many platinum complexes have been shown to inhibit the growth of cancer cells. These compounds have, in general, at least one amino group, which is important for hydrogen-bonding to DNA (Ahmad, Isab, Ali, 2006). Furthermore, the variation of the ligands on the metal centre is a valuable strategy for modeling the physicochemical properties, increasing the uptake of platinum compounds (Graf, Lippard, 2012).

Based on the potential of platinum complexes as anticancer agents and in order to obtain new, more potent and less toxic cisplatin analogues, we set out to synthesize novel cis-diammine platinum complexes, derived from epichlohydrin or pentaerythritol (Figure 1). 


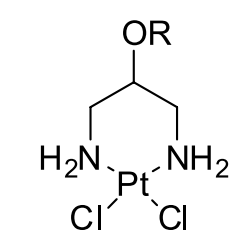

$1 \mathrm{R}=\mathrm{CH}_{2} \mathrm{CH}_{3}$

$2 \mathrm{R}=\left(\mathrm{CH}_{2}\right)_{3} \mathrm{CH}_{3}$

$3 \mathrm{R}=\left(\mathrm{CH}_{2}\right)_{7} \mathrm{CH}_{3}$

$4 \mathrm{R}=\mathrm{CH}_{2} \mathrm{Ph}$

FIGURE 1 - Structure of the platinum complexes synthesized.

The compounds were screened for their ability to inhibit the proliferation of four human cell lines representing breast (MCF-7), colorectal (HCT116), leukaemia (HL-60) and T lymphocytic (Jurkat) cancers. The effects of the different ligands on the cytotoxic activity of platinum complexes have been investigated. Among the synthesized compounds, one was selected for evaluation on mice bearing solid Ehrlich tumor.

\section{MATERIALAND METHODS}

\section{General procedures}

Melting points were determined on a Microquimica MQAPF 301 apparatus and are uncorrected FT-IR spectra were recorded using a Perkin Elmer Spectrum One infrared spectrometer and absorptions are reported as wave numbers $\left(\mathrm{cm}^{-1}\right)$. NMR spectra were recorded on a Bruker Avance DPX 200 SPECTROMETER (200 $\mathrm{MHz})$. Chemical shifts are given in $\delta(\mathrm{ppm})$ scale and $J$ values are given in Hz. All reagents of analytical grade were obtained from commercial suppliers and used without previous purification. Reactions were monitored by TLC using silica gel coated plates and different solvent solutions as the mobile phase. The diazide derivatives 7 (Lopes et al., 2015) and 8 (Bitha et al., 1989) were synthesized according to the published procedure.

General procedure for the preparation of the diazide derivatives 9-14

A $50 \% \mathrm{w} / \mathrm{v}$ aqueous solution of sodium hydroxide was placed into a $50 \mathrm{~mL}$ round bottom flask. Then, a solution of the appropriate diazide (1equivalent) in ethyl ether (double volume regarding the aqueous solution of sodium hydroxide) and $n$-tetrabutylammonium bromide ( 0.3 equivalent) were added to the flask. Finally, the alkyl halide (5 equivalent for the preparation of 9-12 and 10 equivalent for 13-14) was added drop-wise and the reaction mixture was stirred at room temperature until complete consumption of the starting material, as judged by TLC analysis. The reaction mixture was transferred to a separatory funnel and the organic layer was collected. The aqueous layer was extracted with ethyl ether $(4 \times 50 \mathrm{~mL})$. The ethereal phases were combined, washed with water to $\mathrm{pH} 5$, dried (anhydrous $\mathrm{Na}_{2} \mathrm{SO}_{4}$ ), filtered and concentrated to dryness. The crude compound was purified by column chromatography.

\section{1,3-Diazido-2-ethoxypropane (9)}

Oil, $52 \%$ yield. IR ( $\left.\bar{v} / \mathrm{cm}^{-1}\right): 2979,2931$ and 2877 ( $\mathrm{sp}^{3} \mathrm{CH}$ stretching), $2089\left(\mathrm{~N}_{3}\right.$ stretching), 1109 (C-O stretching). ${ }^{1} \mathrm{HNMR}\left(200 \mathrm{MHz}, \mathrm{CDCl}_{3}\right), \delta / \mathrm{ppm}$ : $3.71-$ $3.54\left(3 \mathrm{H}, \mathrm{m}, \mathrm{CHO}\right.$ and $\left.\mathrm{CH}_{2} \mathrm{O}\right) ; 3.33\left(4 \mathrm{H}, \mathrm{d},{ }^{3} J=7 \mathrm{~Hz}, 2 \mathrm{x}\right.$ $\left.\mathrm{C}_{2} \mathrm{~N}_{3}\right) ; 1.25\left(3 \mathrm{H}, \mathrm{t},{ }^{3} \mathrm{~J}=7 \mathrm{~Hz}, \mathrm{C}_{3}\right) .{ }^{13} \mathrm{CNMR}(50 \mathrm{MHz}$, $\left.\mathrm{CDCl}_{3}\right), \delta / \mathrm{ppm}: 77.6(\underline{\mathrm{CHO}}) ; 66.0\left(\underline{\mathrm{CH}}_{2} \mathrm{O}\right) ; 51.6\left(\underline{\mathrm{CH}}_{2} \mathrm{~N}\right)$; $15.3\left(\mathrm{CH}_{3}\right)$.

\section{1,3-Diazido-2-n-butyloxypropane (10)}

Oil, 50\% yield. IR ( $\left.\bar{v} / \mathrm{cm}^{-1}\right): 2960,2934$ and 2872 ( $\mathrm{sp}^{3} \mathrm{CH}$ stretching), 2091 ( $\mathrm{N}_{3}$ stretching), 1111 (C-O stretching). ${ }^{1} \mathrm{HNMR}\left(200 \mathrm{MHz}, \mathrm{CDCl}_{3}\right), \delta / \mathrm{ppm}$ : 3.62$3.51\left(3 \mathrm{H}, \mathrm{m}, \mathrm{C} \underline{\mathrm{HO}}\right.$ and $\left.\mathrm{C}_{2} \mathrm{O}\right) ; 3.34\left(4 \mathrm{H}, \mathrm{d},{ }^{3} \mathrm{~J}=5 \mathrm{~Hz}, 2 \mathrm{x}\right.$ $\left.\mathrm{C}_{\mathrm{H}_{2}} \mathrm{~N}_{3}\right)$; 1.67-1.49 (2H, m, $\left.\underline{\mathrm{H}}_{2}\right)$; 1.46-1.31 (2H, m, $\left.\mathrm{C}_{2}\right)$; $0.93\left(3 \mathrm{H}, \mathrm{t},{ }^{3} \mathrm{~J}=7 \mathrm{~Hz}, \mathrm{C}_{3}\right) .{ }^{13} \mathrm{CNMR}\left(50 \mathrm{MHz}, \mathrm{CDCl}_{3}\right), \delta /$ ppm: $77.8(\underline{\mathrm{CHO}}) ; 70.5\left(\underline{\mathrm{CH}}_{2} \mathrm{O}\right) ; 52.0\left(\underline{\mathrm{CH}}_{2} \mathrm{~N}\right) ; 31.9\left(\underline{\mathrm{CH}}_{2}\right)$; $19.1\left(\underline{\mathrm{CH}}_{2}\right) ; 13.8\left(\underline{\mathrm{CH}}_{3}\right)$.

\section{1,3-Diazido-2-octyloxypropane (11)}

Oil, 63\% yield. IR ( $\left.\bar{v} / \mathrm{cm}^{-1}\right): 2926$ and $2856\left(\mathrm{sp}^{3} \mathrm{CH}\right.$ stretching), 2093 ( $\mathrm{N}_{3}$ stretching), 1111 (C-O stretching); $723\left(\mathrm{CH}_{2}\right.$ rocking). ${ }^{1} \mathrm{HNMR}\left(200 \mathrm{MHz}, \mathrm{CDCl}_{3}\right), \delta / \mathrm{ppm}$ : 3.61-3.51 (3H, m, C브 and $\left.\mathrm{CH}_{2} \mathrm{O}\right) ; 3.34\left(4 \mathrm{H}, \mathrm{d},{ }^{3} \mathrm{~J}=7\right.$ $\left.\mathrm{Hz}, 2 \mathrm{x} \mathrm{C}_{2} \mathrm{~N}_{3}\right) ; 1.65-1.56\left(2 \mathrm{H}, \mathrm{m}, \mathrm{CH}_{2}\right) ; 1.45-1.15(10 \mathrm{H}$, $\left.\mathrm{m}, \mathrm{C}_{2}\right) ; 0.88\left(3 \mathrm{H}, \mathrm{t},{ }^{3} \mathrm{~J}=6 \mathrm{~Hz}, \mathrm{CH}_{3}\right) .{ }^{13} \mathrm{CNMR}(50 \mathrm{MHz}$, $\left.\mathrm{CDCl}_{3}\right), \delta /$ ppm: $77.8(\underline{\mathrm{C}} \mathrm{HO}) ; 70.6\left(\underline{\mathrm{CH}}_{2} \mathrm{O}\right) ; 51.7\left(\underline{\mathrm{CH}}_{2} \mathrm{~N}\right)$; $31.7\left(\underline{\mathrm{CH}}_{2}\right) ; 29.8\left(\underline{\mathrm{CH}}_{2}\right) ; 29.3\left(\underline{\mathrm{CH}}_{2}\right) ; 29.1\left(\underline{\mathrm{CH}}_{2}\right) ; 25.9$ $\left(\underline{\mathrm{CH}}_{2}\right) ; 22.5\left(\underline{\mathrm{CH}}_{2}\right) ; 15.3\left(\underline{\mathrm{CH}}_{3}\right)$.

\section{1,3-Diazido-2-benzyloxypropane (12)}

Oil, $45 \%$ yield. IR $\left(\bar{v} / \mathrm{cm}^{-1}\right): 3032(\operatorname{arom~CH}$ stretching), 2930 and 2869 ( $\mathrm{sp}^{3} \mathrm{CH}$ stretching), $2090\left(\mathrm{~N}_{3}\right.$ stretching), 1496 and 1494 (arom C=C stretching), 1095 (C-O stretching), 737, 696 (CH bending, phenyl). ${ }^{1} \mathrm{HNMR}$ $\left(200 \mathrm{MHz}, \mathrm{CDCl}_{3}\right), \delta / \mathrm{ppm}: 7.43(5 \mathrm{H}$, broad singlet, $\left.\mathrm{C}_{6} \underline{\mathrm{H}}_{5}\right) ; 4.70\left(2 \mathrm{H}, \mathrm{s}, \mathrm{C}_{2} \mathrm{O}\right) ; 3.71\left(1 \mathrm{H}, \mathrm{q},{ }^{3} \mathrm{~J}=5.8, \mathrm{C} \underline{\mathrm{HO}}\right)$; $3.39\left(4 \mathrm{H}, \mathrm{d},{ }^{3} \mathrm{~J}=5.8 \mathrm{~Hz}, 2 \mathrm{C} \mathrm{C}_{2} \mathrm{~N}_{3}\right) \cdot{ }^{13} \mathrm{CNMR}(50 \mathrm{MHz}$, $\mathrm{CDCl}_{3}$ ), $\delta$ /ppm: 137.2 (C ipso); 128.5 (C para); 128.1 (C meta); 127.9 (C ortho), 76.9 ( $\underline{\mathrm{CHO}}) ; 72.4\left(\underline{\mathrm{CH}}_{2} \mathrm{O}\right)$; $51.6\left(\underline{\mathrm{CH}}_{2} \mathrm{~N}\right)$. 


\section{2,2-Bis(2-azidomethyl)-1,3-bis(ethoxy)propane (13)}

Oil, $43 \%$ yield. IR ( $\left.\bar{v} / \mathrm{cm}^{-1}\right): 2977,2934,2871$ and 2804 ( $\mathrm{sp}^{3} \mathrm{CH}$ stretching), 2093 ( $\mathrm{N}_{3}$ stretching), 1105 (C-O stretching). ${ }^{1} \mathrm{HNMR}\left(200 \mathrm{MHz}, \mathrm{CDCl}_{3}\right), \delta / \mathrm{ppm}: 3.46(4 \mathrm{H}$, q, $\left.{ }^{3} J=7 \mathrm{~Hz}, \mathrm{CH}_{2} \mathrm{O}\right) ; 3.33\left(4 \mathrm{H}, \mathrm{s}, 2 \mathrm{x} \mathrm{C} \underline{\mathrm{H}}_{2} \mathrm{O}\right) ; 3.30(4 \mathrm{H}, \mathrm{s}$, $\left.2 \times \underline{\mathrm{C}}_{2} \mathrm{~N}\right) ; 1.17\left(6 \mathrm{H}, \mathrm{t},{ }^{3} \mathrm{~J}=7 \mathrm{~Hz}, 2 \times \mathrm{C}_{3}\right) .{ }^{13} \mathrm{CNMR}(50$ $\left.\mathrm{MHz}, \mathrm{CDCl}_{3}\right), \delta / \mathrm{ppm}: 68.9\left(\underline{\mathrm{CH}}_{2} \mathrm{O}\right) ; 66.7\left(\underline{\mathrm{CH}}_{2} \mathrm{O}\right) ; 51.8$ $\left(\underline{\mathrm{CH}}_{2} \mathrm{~N}\right) ; 45.1$ (quaternary $\left.\mathrm{C}\right) ; 14.9\left(\underline{\mathrm{CH}}_{3}\right)$.

\section{2,2-Bis(2-azidomethyl)-1,3-bis(butyloxy)propane (14)}

Oil, $35 \%$ yield. IR ( $\left.\bar{v} / \mathrm{cm}^{-1}\right): 2959,2934,2867$ and 2801 ( $\mathrm{sp}^{3} \mathrm{CH}$ stretching), $2094\left(\mathrm{~N}_{3}\right.$ stretching), 1100 (C-O stretching). ${ }^{1} \mathrm{HNMR}\left(200 \mathrm{MHz}, \mathrm{CDCl}_{3}\right), \delta / \mathrm{ppm}$ :

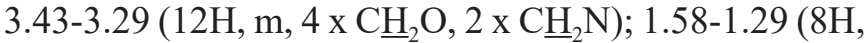
$\left.4 \times \mathrm{CH}_{2}\right) ; 0.91\left(6 \mathrm{H}, \mathrm{t},{ }^{3} \mathrm{~J}=7 \mathrm{~Hz}, 2 \times \mathrm{CH}_{3}\right){ }^{13} \mathrm{CNMR}(50$ $\left.\mathrm{MHz}, \mathrm{CDCl}_{3}\right), \delta /$ ppm: $71.2\left(\underline{\mathrm{CH}}_{2} \mathrm{O}\right) ; 69.2\left(\underline{\mathrm{CH}}_{2} \mathrm{O}\right) ; 51.8$ $\left(\underline{\mathrm{CH}}_{2} \mathrm{~N}\right) ; 45.1$ (quaternary C); $31.4\left(\mathrm{C}_{2}\right) ; 19.4\left(\mathrm{C}_{2}\right)$; $13.8\left(\mathrm{CH}_{3}\right)$.

\section{General procedures for the preparation of diamines}

\section{5-17 and 19-20: catalytic hydrogenation}

A solution of the he appropriately alkylated diazide (1 equivalent) in methanol was placed into a $50 \mathrm{~mL}$ round bottom flask. Palladium $10 \%$ on carbon $(40 \%$ of the weight of the diazide) was added and the heterogeneous mixture was stirred at room temperature under a hydrogen atmosphere until complete consumption of the starting material, as judged by TLC analysis. The catalyst was removed by filtration and the solvent distilled off using a rotary evaporator. The crude compound was used in the next step without further purification.

Procedure for the preparation of diamine 18:

Staudinger reduction with triphenylphosphine

A solution of diazide 12 (1 eq) and triphenylphosphine (2 eq) in tetrahydrofuran $(5 \mathrm{~mL})$ was added to a $25 \mathrm{~mL}$ round bottom flask. The reaction mixture was set aside until the complete consumption of the starting material, as judged by TLC analysis. The solvent was removed with a stream of nitrogen and the residue dissolved in $\mathrm{HCl} 1 \mathrm{~mol}$ $\mathrm{L}^{-1}$. This solution was transferred to a separatory funnel and extracted with ethyl acetate $(5 \times 30 \mathrm{~mL})$ to remove impurities. The acidic solution was then evaporated to dryness to furnish the diamine $\mathbf{1 8}$ in the form of a hygroscopic dihydrochloride.

\section{2-Ethoxy-1,3-diaminopropane (15)}

Oil, $86 \%$ yield. IR $\left(\bar{v} / \mathrm{cm}^{-1}\right): 3400,3290(\mathrm{NH}$ stretching), 2973, 2928, 2872 ( $\mathrm{sp}^{3} \mathrm{CH}$ stretching), 1571 (NH bending), 1082 (C-O stretching).
2-Butyloxy-1,3-diaminopropane (16)

Oil, $74 \%$ yield. IR $\left(\bar{v} / \mathrm{cm}^{-1}\right): 3364,3294(\mathrm{NH}$ stretching), 2957, 2932, 2868 ( $\mathrm{sp}^{3} \mathrm{CH}$ stretching), 1587 (NH bending), 1100 (C-O stretching).

\section{2-Octyloxy-1,3-diaminopropane (17)}

Oil, $95 \%$ yield. IR $\left(\bar{v} / \mathrm{cm}^{-1}\right): 3241,3190(\mathrm{NH}$ stretching), 2922, 2852 ( $\mathrm{sp}^{3} \mathrm{CH}$ stretching), 1585 (NH bending), 1103 (C-O stretching), $723\left(\mathrm{CH}_{2}\right.$ rocking).

\section{2-Benzyloxy-1,3-diaminopropane (18)}

Oil, $80 \%$ yield. IR $\left(\bar{v} / \mathrm{cm}^{-1}\right): 3400,3290(\mathrm{NH}$ stretching), 2973, 2928, 2872 ( $\mathrm{sp}^{3} \mathrm{CH}$ stretching), 1571 (NH bending), 1082 (C-O stretching), 744, 700 (CH bending, phenyl).

\section{2,2-Bis(2-aminoethyl)-1,3-bis(ethoxy)propane (19)}

Oil, $86 \%$ yield. IR $\left(\bar{v} / \mathrm{cm}^{-1}\right): 3373,3270(\mathrm{NH}$ stretching), 2974, 2932, 2867 ( $\mathrm{sp}^{3} \mathrm{CH}$ stretching), 1571 (NH bending), 1102 (C-O stretching).

\section{2,2-Bis(2-aminoethyl)-1,3-bis(butyloxy)propane (20)}

Oil, $89 \%$ yield. IR $\left(\bar{v} / \mathrm{cm}^{-1}\right): 3430,3292(\mathrm{NH}$ stretching), 2957, 2931, 2863 ( $\mathrm{sp}^{3} \mathrm{CH}$ stretching), 1579 (NH bending), 1103 (C-O stretching).

\section{General procedure: synthesis of platinum complexes}

To an aqueous solution of $\mathrm{K}_{2} \mathrm{PtCl}_{4}$ was added dropwise an equimolar amount of the appropriate diamine derivative dissolved in water. The reaction mixture was stirred for 90 minutes at room temperature, the complex which precipitates was filtrated, washed with distilled water an dried.

\section{Complex 1}

Solid, m.p. $215^{\circ} \mathrm{C}$ (decomposition), $19 \%$ yield. IR $\left(\bar{v} / \mathrm{cm}^{-1}\right): 3600-3100,\left(\mathrm{NH}\right.$ stretching), 2970, $2850\left(\mathrm{sp}^{3} \mathrm{CH}\right.$ stretching), 1572 (NH bending), 1040 (C-O stretching), 485, 415 (Pt-N stretching), 347, 303 (Pt-Cl stretching).

\section{Complex 2}

Solid, m.p. $199{ }^{\circ} \mathrm{C}$ (decomposition), 55\% yield. IR ( $\left./ \mathrm{cm}^{-1}\right): 3600-3100,\left(\mathrm{NH}\right.$ stretching), 2959, $2872\left(\mathrm{sp}^{3} \mathrm{CH}\right.$ stretching), 1587 (NH bending), 1106 (C-O stretching), 531, 429 (Pt-N stretching), 329, 312 (Pt-Cl stretching).

\section{Complex 3}

Solid, m.p. $194{ }^{\circ} \mathrm{C}$ (decomposition), 50\% yield. IR $\left(\bar{v} / \mathrm{cm}^{-1}\right): 3600-3100$, (NH stretching), 2928, $2856\left(\mathrm{sp}^{3} \mathrm{CH}\right.$ stretching), 1578 (NH bending), 1105 (C-O stretching), 468 (Pt-N stretching), 312 (Pt-Cl stretching). 


\section{Complex 4}

Solid, m.p. $281^{\circ} \mathrm{C}$ (decomposition), $12 \%$ yield. IR $\left(\bar{v} / \mathrm{cm}^{-1}\right)$ : 3600-3100, (NH stretching), 2936, 2856 ( $\mathrm{sp}^{3} \mathrm{CH}$ stretching), 1571 ( $\mathrm{NH}$ bending), 1091 (C-O stretching), 740, 698 ( $\mathrm{CH}$ bending, phenyl), 470 (Pt-N stretching), 328, 318 (Pt-Cl stretching).

\section{Complex 5}

Solid, m.p. $211^{\circ} \mathrm{C}$ (decomposition), 30\% yield. IR ( $\left.\overline{\mathrm{v}} / \mathrm{cm}^{-1}\right)$ : 3600-3100, (NH stretching), 2974, 2932, 2871 ( $\mathrm{sp}^{3} \mathrm{CH}$ stretching), 1587 ( $\mathrm{NH}$ bending), 1112 (C-O stretching), 472 (Pt-N stretching), 324, 312 (Pt-Cl stretching).

\section{Complex 6}

Solid, m.p. $257^{\circ} \mathrm{C}$ (decomposition), $41 \%$ yield. IR ( $\left.\overline{\mathrm{v}} / \mathrm{cm}^{-1}\right): 3600-3100$, (NH stretching), 2958, $2872\left(\mathrm{sp}^{3} \mathrm{CH}\right.$ stretching), 1584 (NH bending), 1120 (C-O stretching), 457 (Pt-N stretching), 323 (Pt-Cl stretching).

Cytotoxicity assays. The screening assays were performed in 96 well plates pre-incubated for $24 \mathrm{~h}$ at $37^{\circ} \mathrm{C}$ to allow adaptation of cells prior to the addition of the compounds at $50 \mu \mathrm{M}$. Treated and untreated cells (DMSO 0.5\%) were incubated for 48 hours and compounds that inhibited the cell viability greater than $50 \%$ had the $\mathrm{IC}_{50}$ values obtained graphically from concentration-effect curves using Prism 5.0 (GraphPad Software Inc.). Cisplatin was used as positive control under the same experimental conditions. All substances were evaluated in two independent experiments, in triplicate. Cell viability was estimated by MTT assay (Mosmann, 1983).

In vivo experiments. Female Swiss albino mice weighing 25-30 g, 6 weeks old, were obtained from Faculdade de Farmácia da Universidade Federal de Minas Gerais. The animals were housed in plastic cages with free access to food and water. The protocol was approved by the Ethics Committee for Animal Experiments at the Universidade Federal de Minas Gerais (protocol 236/2013) and are in compliance with the guide for the care and use of laboratory animals recommended by the Institute of Laboratory Animal Resources.

\section{Ehrlich solid tumor}

Ehrlich ascites tumor (EAT) cells from the peritoneal cavity of Swiss mice were cultured and solid tumors were induced as previously described by us (Lages et al., 2013). Briefly, solid tumors were induced in mice by subcutaneous inoculation of $0.2 \mathrm{~mL}$ containing $3 \times 10^{6}$ viable tumor cells on the left flank. After the inoculation of Ehrlich ascites tumor cells, over 90 per cent of the mice developed solid tumors. Tumor growth was determined by caliper measurement of the largest diameter and its perpendicular. Tumor size was calculated as: tumor size $\left(\mathrm{mm}^{3}\right)=\mathrm{ax}(\mathrm{b})^{2} / 2$, where a: the largest diameter and; $\mathrm{b}$ is its perpendicular.

When the primary tumor reached a size of approximately $290 \mathrm{~mm}^{3}$ (day 0), animals were divided into three groups, each composed of 6 mice. Groups 1: control group treated only with a mixture of dimethylacetamide (DMA): PEG-300:Tween 80:saline (6:9:5:80 v/v); Group 2: group treated with complex $3(4 \mathrm{mg} / \mathrm{kg})$, twice a week for a period of 2 weeks; and Group 3: group treated with cisplatin $(4 \mathrm{mg} / \mathrm{kg})$. The compounds was dissolved in a mixture of DMA:PEG-300:Tween 80:saline (6:9:5:80) so that the volume to be administered to each animal was $0.1 \mathrm{ml}$. The mice were treated by intratumoral injection. At the end of the experiments, the animals were euthanized by cervical dislocation under anesthesia with a ketaminexylazine mixture.

\section{Statistical analysis}

All data are presented as mean $\pm \mathrm{sd}$. Data were analyzed using the Minitab software (version 14.0). Statistical significance of differences between data was evaluated by General Linear Model ANOVA using the $t$ student test. A value of $p<0.05$ was considered significant.

\section{RESULTS AND DISCUSSION}

The platinum complexes 1-6 were synthesized using the corresponding diazide derivatives $\mathbf{7}$ and $\mathbf{8}$ as key intermediates. The azido-alcohols 7 and $\mathbf{8}$ were used in the synthesis of the azido-ethers $\mathbf{9 - 1 4}$ by phase-transfer catalyzed alkylations, which, except for $\mathbf{1 2}$, were reduced under hydrogenation conditions in presence of $\mathrm{Pd} / \mathrm{C}$ to afford the corresponding diamine derivative 15-20 in 74$95 \%$ yield. Chemoselective reduction of compound 12 was achieved following the method described by Staudinger, Meyer (1919), using triphenylphosphine. The platinum complexes 1-6 were synthesized by reaction of equimolar amount of the appropriate diamine with $\mathrm{K}_{2} \mathrm{PtCl}_{4}$, in $12-55 \%$ (Scheme 1).

The platinum complexes 1-6 were assayed in vitro at $50 \mu \mathrm{M}$ against four human cancer cells lines MCF-7 (breast), HCT116 (colorectal), HL-60 (leukaemia) and Jurkat (T lymphocytic), using cisplatin as standard control drug. The concentrations that cause 50\% inhibition of the tumor cell growth $\left(\mathrm{GI}_{50}\right)$ were evaluated for the more potent compounds (those presenting more than 

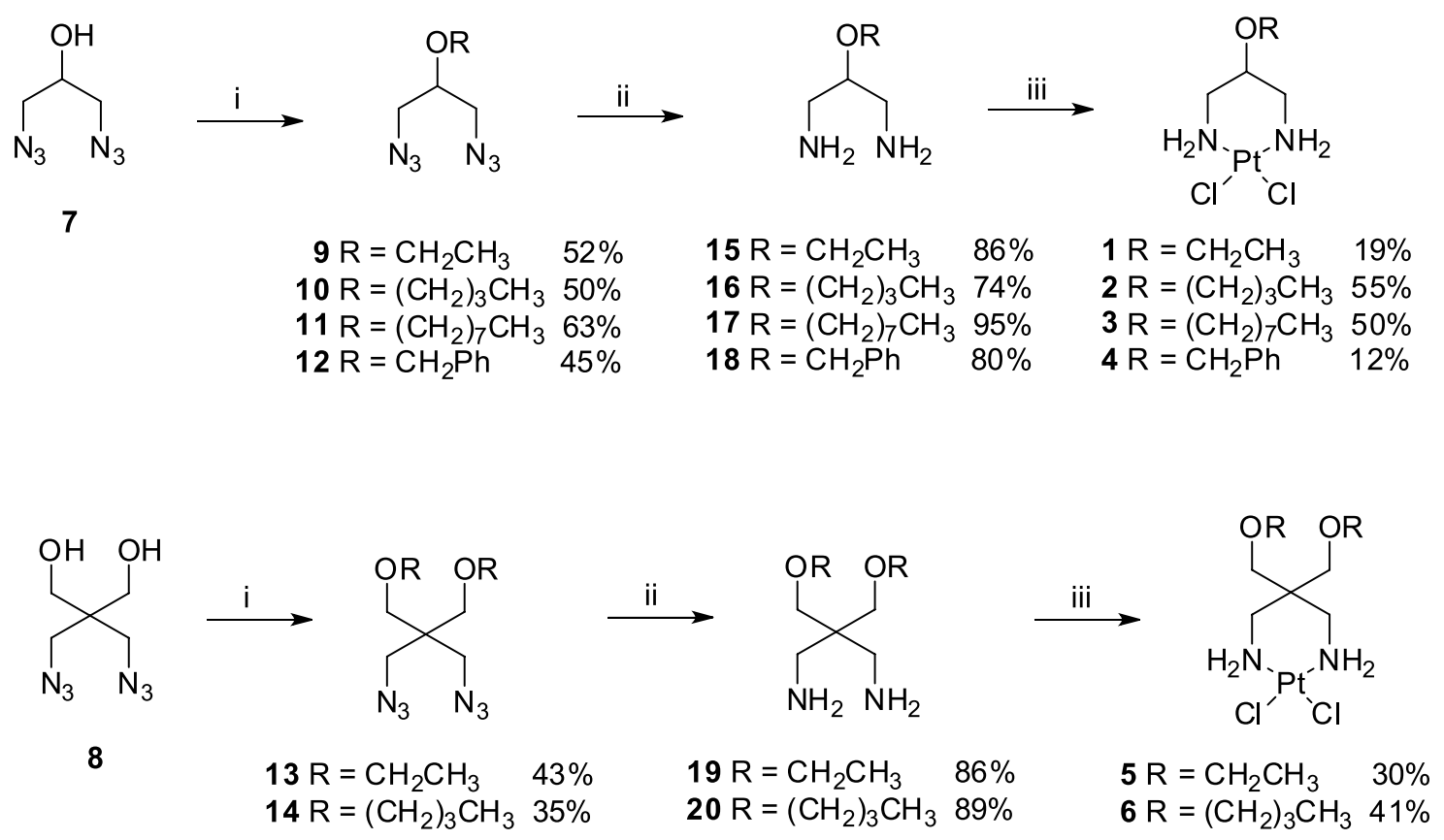

$\mathrm{i}=\mathrm{RX}, \mathrm{NaOH}, \mathrm{Bu}_{4} \mathrm{NBr}, \mathrm{CH}_{2} \mathrm{Cl}_{2} / \mathrm{H}_{2} \mathrm{O} ; \mathrm{ii}=\mathrm{H}_{2}$, Pd C, except for 12, which was reduced in Staundinger conditions; $\mathrm{iii}=\mathrm{K}_{2} \mathrm{PtCl}_{4}, \mathrm{H}_{2} \mathrm{O}$

SCHEME 1 - Synthetic route for the preparation of platinum complexes 1-6.

$50 \%$ inhibition in the initial screening). The results are summarized in Table I.

Based on the results shown in Table I, platinum complex 1 was inactive against all of the tested tumor cell lines. All other complexes were able to inhibit more than $50 \%$ of the growth of at least one of the cancer cell lines and then their $\mathrm{GI}_{50}$ values were determined $\left(\mathrm{IC}_{50}=4-51 \mu \mathrm{M}\right)$. The human acute myeloid leukemia cell line HL60 was more sensitive to the action of the compounds. Complexes $\mathbf{3}$ and $\mathbf{6}$ showed activity comparable to cisplatin $\left(\mathrm{CI}_{50}=\right.$ $2.1 \mu \mathrm{M}$ ) against $\mathrm{HL}-60$ cells, with $\mathrm{CI}_{50}$ values in the lowmicromolar range ( 6 and $4 \mu \mathrm{M}$, respectively). Complexes 3 and $\mathbf{6}$ can be considered the most promising compounds since they were active against all the assayed tumor cell lines, with emphasis on their cytotoxic activity against the human breast cancer cell lines MCF-7, which was resistant to the action of cisplatin. These results suggest that the presence of longer alkyl chain is favorable for the activity, perhaps by facilitating the penetration of these complexes into the tumor cells.

Based on the results of in vitro cytotoxicity assay, the compound $\mathbf{3}$ was selected for further in vivo evaluation in a mouse model bearing solid Ehrlich tumor. Solid tumor was induced in female Swiss albino mice by inoculation of Ehrlich ascites tumor cells as previously described by us (Lages et al., 2013). Due to its low aqueous solubility,
TABLE I - Effects of platinum complexes 1-6 on the growth of human cancer cells lines

\begin{tabular}{|c|c|c|c|c|}
\hline $\begin{array}{l}1 \mathrm{R} \\
2 \mathrm{R} \\
3 \mathrm{R} \\
4 \mathrm{R}\end{array}$ & $\begin{array}{l}\mathrm{Cl}_{2} \\
\mathrm{H}_{2} \mathrm{CH}_{3} \\
\left.\mathrm{CH}_{2}\right)_{3} \mathrm{CH}_{3} \\
\left.\mathrm{CH}_{2}\right)_{7} \mathrm{CH}_{3} \\
\mathrm{H}_{2} \mathrm{Ph}\end{array}$ & & $\begin{array}{l}\mathrm{OR} \\
=\mathrm{CH}_{2} \mathrm{Cl} \\
=\left(\mathrm{CH}_{2}\right)_{3}\end{array}$ & \\
\hline \multirow{2}{*}{ Compound } & \multicolumn{4}{|c|}{$\mathrm{GI}_{50}(\mu \mathrm{M})$} \\
\hline & Jurkat & HL60 & MCF-7 & НCT-116 \\
\hline 1 & $>50$ & $>50$ & $>50$ & $>50$ \\
\hline 2 & $>50$ & 11.9 & $>50$ & $>50$ \\
\hline 3 & 51.1 & 6.4 & 13.7 & 27.3 \\
\hline 4 & $>50$ & 9.5 & $>50$ & $>50$ \\
\hline 5 & $>50$ & 15.6 & $>50$ & $>50$ \\
\hline 6 & 23.3 & 4.0 & 20.7 & 22.0 \\
\hline cisplatin & 11.7 & 2.1 & $>50$ & 12.6 \\
\hline
\end{tabular}


3 was dispersed in a mixture of dimethylacetamide (DMA), polyethylene glycol (PEG-300), Tween 80 and saline $(6: 9: 5: 80 \mathrm{v} / \mathrm{v})$ and administered by intratumoral injection at a dose of $4 \mathrm{mg} / \mathrm{Kg}$. A group of animals treated with vehicle alone $(n=6)$ and a group of animals treated with cisplatin at a dose of $4 \mathrm{mg} / \mathrm{Kg}(\mathrm{n}=6)$ were included as negative and positive controls, respectively. The mice were treated twice per week for 2 weeks.

In the first week of treatment, a marked delay in the rate of tumor growth, compared with that of the control group $(\mathrm{p}<0.05)$, was observed in the groups treated with complex 3 and cisplatin. However, tumor growth increased significantly after the eighth day of treatment with $\mathbf{3}$, reaching a size similar to the control group $(\mathrm{p}>0.05)$ (Figure 2 ). In contrast, the tumor volume of cisplatin-treated group continued to decrease with time and two animals showed complete regression of the tumor. It is noteworthy that only mice treated with cisplatin exhibited signs of toxicity, such as decreased activity, piloerection and weight loss, and two animals died before the end of the experiments.

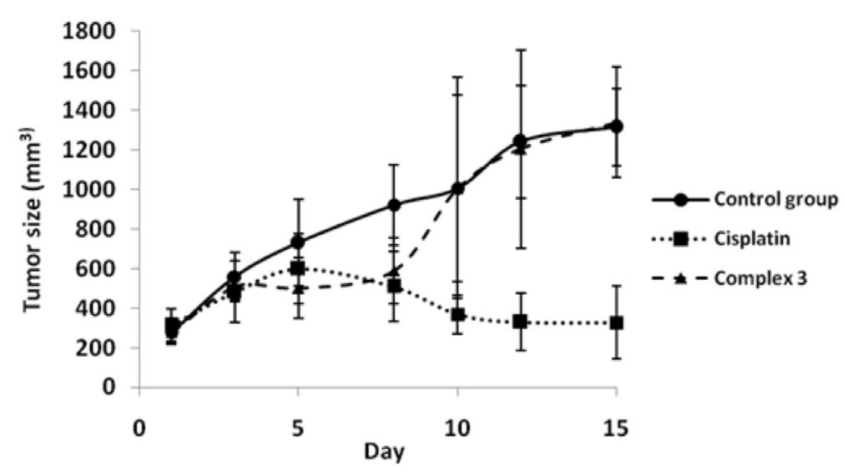

FIGURE 2 - Antitumor effect of complex 3 and cisplatin 4 $\mathrm{mg} / \mathrm{kg}$ in a mice using model of Ehrlich solid tumor. Results represent the tumor size after treatment $($ mean $\pm \mathrm{sd})$ of different experimental groups $(n=6)$.

The variation in the activity of complex $\mathbf{3}$ may be due to the practical difficulty of administration of a homogeneous dose, because of its relatively low solubility in vehicle. Lipophilic drugs can penetrate into cells more easily, but, on the other hand, they can be too insoluble in aqueous solution, preventing their use in vivo. The administration of lower dose, use of other vehicles or formulation options to deliver low-solubility compounds are alternatives that can be used in further studies. It is worth noting that de molecular mass of $3(\mathrm{MM}=468.33)$ is 1.56 higher than that of cisplatin $(\mathrm{MM}=300.01)$, so less amount of the compound in a molar basis was used. This, together with its low solubility indicates, in our view, that the compound deserves further investigation.

\section{CONCLUSION}

In conclusion, six platinum (II) complexes have been synthesized and tested as potential antiproliferative agents against four cancer cell lines: breast (MCF-7), colorectal (HCT116), leukaemia (HL-60) and T lymphocytic (Jurkat). Five of them were found to be effective against at least one tumor cell line, at micromolar concentrations. Based on the results of in vitro cytotoxicity assay, the platinum complex $\mathbf{3}$, having an alkyl chain of 8 carbon atoms, was selected for evaluation on mice bearing solid Ehrlich tumor. This compound showed antitumor activity only in the first half of the treatment. Further studies aimed at enhancing the solubility of compound $\mathbf{3}$ in the assay conditions are needed to confirm its antitumor potential.

\section{ACKNOWLEDGMENTS}

The authors are grateful to Fundação de Amparo à Pesquisa do Estado de Minas Gerais (FAPEMIG) and Conselho Nacional de Desenvolvimento Científico e Tecnológico (CNPq), for financial support.

\section{REFERENCES}

AHMAD, S.; ISAB, A.A.; ALI, S. Structural and mechanistic aspects of platinum anticancer agents. Transit. Metal. Chem., v.31, n.8, p.1003-1016, 2006.

BITHA, P.; CARVAJAL, S.G.; CITARELLA, R.V.; CHILD, R.G.; SANTOS, E.F.D.; DUNNE, T.S.; DURR, F.E.; HLAYKA, J.J.; LANG Jr., S.A.; LINDSAY, H.L.; MORTON, G.O.; THOMAS, J.P.; WALLACE, R.E.; LIN, Y.; HALTIWANGER, R.C.; PIERPONT, C.G. Water-soluble third generation antitumor platinum complexes, [2,2-bis(aminomethyl)-1,3-propanediol- $N, N^{\prime}$ [1,1-cyclobutanedicarboxylato(2-)-O,O'] platinum(II) and [1,1-cyclobutanedicarboxylato(2-)-O,O'][tetrahydro-4Hpyran-4,4-dimethanamine- $N, N$ '] platinum(II). J. Med. Chem., v.32, n.8, p.2015-2020, 1989.

FLOREA, A.M.; BÜSSELBERG, D. Cisplatin as an anti-tumor drug: cellular mechanisms of activity, drug resistance and induced side effects. Cancers, v.3, n.1, p.1351-1371, 2011.

GÓMEZ-RUIZ, S.; MAKSIMOVIC-IVANIC, D.; MIJATOVIC, S.; KALUDEROVIC, G. On the discovery, biological effects, and use of cisplatin and metallocenes in anticancer chemotherapy. Bioinorg. Chem. Appl., v.2012, p.1-14, 2012. 
GRAF, N.; LIPPARD, J. Redox activation of metal-based prodrugs as a strategy for drug delivery. Adv. Drug Deliv. Rev., v.64, n.11, p.993-1004, 2012.

HILDEBRANDT, J.; HÄFNER, N.; GÖRLS, H.; KRITSCH, D.; FERRARO, G.; DÜRST, M.; RUNNEBAUM, I.B.; MERLINO, A.; WEIGAND, W. Platinum(II) O,S complexes as potential metallodrugs against Cisplatin resistance. Dalton Trans., v.45, n.47, p.18876-18891, 2016.

LAGES, E.B.; FREITAS, M.B.; GONÇALVES, I.M.B.; ALVES, R.J.; VIANNA-SOARES, C.D.; FERREIRA, L.A.M.; OLIVEIRA, M.C.; OLIVEIRA, R.B. Evaluation of antitumor activity and development of solid lipid nanoparticles of metronidazole analogue. J. Biomed. Nanotechnol., v.9, n.11, p.1939-1944, 2013.

LAKOMSKA, I.; BABINSKA, M.; WOJTCZAK, A.; SITKOWSKI. Synthesis, characterization and in vitro cytotoxicity of three types of platinum (II) complexes containing 5,7-diethyl-1,2,4-triazolo[1,5-a]pyrimidine. Inorg. Chim. Acta, v.453, p.516-521, 2016.

LOPES, M.S.; SENA, C.F.A.; SILVA, B.L.; SOUZA, C.M.; RAMOS, J.P.; CASSALI, G.D.; SOUZA-FAGUNDES, E.M.; ALVES, R.J.; OLIVEIRA, M.C.; OLIVEIRA, R.B. Synthesis of nitroaromatic compounds as potential anticancer agents. Anticancer Agents Med. Chem., v.15, n.2, p.206-216, 2015.

MOSMANN, T. Rapid colorimetric assay for cellular growth and survival: application to proliferation and cytotoxicity assays. J. Immunol. Methods, v.65, n.1/2, p.55-63, 1983.

POLLAK, D.; GODDARD, R.; PÖRSCHKE, K.R. Synthesis and structures of 9-oxabispidine analogues of cisplatin, carboplatin, and oxaliplatin. Inorg. Chem., v.55, n.18, p.9424-9435, 2016.
POPOVA, E.A.; SEREBRYANSKAYA, T.V.; SELIVANOV, S.I.; HAUKKA, M.; PANIKOROVSKY, T.L.; GURZHIY, V.V.; OTT, I.; TRIFONOV, R.E.; KUKUSHKIN, V.Y. Water-soluble platinum (II) complexes featuring 2-alkyl2Htetrazol-5-ylacetic acids: synthesis, characterization, and antiproliferative activity. Eur. J. Inorg. Chem., v.2016, n.28, p.4659-4667, 2016.

REHM, T.; ROTHEMUND, M.; MUENZNER, J.K.; NOOR, A.; KEMPE, R.; SCHOBERT, R. Novel cis-[(NHC) ${ }^{1}(\mathrm{NHC})^{2}(\mathrm{~L})$ $\mathrm{Cl}$ platinum (II) complexes - synthesis, structures, and anticancer activities. Dalton Trans., v.45, n.39, p.1539015398, 2016.

STAUDINGER, H.; MEYER, J. Über neue organische phosphorverbindungen III. Phosphinmethylenderivate und phosphinimine. Helv. Chim. Acta, v.2, n.1, p.635-646, 1919.

WANG, Q.W.; LAM, P.L; WONG, R.S.M.; CHENG, G.Y.M.; LAM, K.H.; BIAN, Z.X.; HO, C.L.; FENG, Y.H.; GAMBARI, R.; LO, Y.H.; WONG, W.Y.; CHUI, C.H. Synthesis of platinum (II) and palladium (II) complexes with 9,9-dihexyl-4,5-diazafluorene and their in vivo antitumor activity against Hep3B xenografted mice. Eur. J. Med. Chem., v.124, p.537-543, 2016.

WORLD HEALTH ORGANIZATION. WHO. Cancer. 2015. Available from: <http:/www.who.int/topics/cancer/en/>. Accessed on: 15 Sept. 2015.

Received for publication on $25^{\text {th }}$ November 2015 Accepted for publication on $26^{\text {th }}$ October 2016 